\title{
Streptomyces sannanensis sp. nov.
}

\author{
AKIO IWASAKI, HISAKATSU ITOH, AND TOSHIHITO MORI \\ Tokyo Research Laboratories, Kowa Co., Ltd., Higashimurayama, Tokyo 189, Japan
}

\begin{abstract}
A new species of bacteria is described for which the name Streptomyces sannanensis is proposed. The organism produces new aminoglycoside antibiotics, the sannamycin complex. The species is characterized by its gray spore mass color, coiled spore chains, spores with smooth surfaces, nonchromogenicity, and carbon utilization pattern. It differs from known streptomycetes on the basis of its carbon utilization characteristics and its production of the sannamycin complex of antibiotics. The type strain of S. sannanensis is strain KC-7038, which was deposited at the American Type Culture Collection under the number 31530.
\end{abstract}

A streptomycete, strain KC-7038, was found in the course of our screening program for new antibiotics. The organism produces the sannamycin complex (2), components of which have structures related to the known aminoglycoside antibiotics, namely the fortimicins (4), the sporaricins (3), the istamycins (8), and dactimicin (18). Those antibiotics were produced by Micromonospora sp. MK-70 (7), "Saccharopolyspora hirsuta subsp. kobensis" (5), "Streptomyces tenjimariensis" (8), and "Dactylosporangium matsuzakiense" (18), respectively. (Note: Names enclosed in quotation marks are not on the Approved Lists of Bacterial Names (19) and to date they have not been validly published.) The strain belongs to the genus Streptomyces Waksman and Henrici because of its cell wall composition and its good agreement with other criteria characteristic for Streptomyces. The following report concerns a taxonomic study of this organism.

\section{MATERIALS AND METHODS}

Bacterial strains. Strain KC-7038 was isolated in our laboratory from a soil sample collected in Sannan Town, Hikami District, Hyogo Prefecture, Japan. "Streptomyces pyridomyceticus" $(9,15,21)$ ISP 5024 was compared to strain $\mathrm{KC}-7038$ because they appeared to be related.

Morphological characteristics. Morphological observations were made under an optical microscope and an electron microscope (model HS-9, Hitachi, Ltd.), if necessary, on cultures which had been grown at $27^{\circ} \mathrm{C}$ for 14 days on yeast extract-malt extract agar (International Streptomyces Project [ISP] medium no. 2), oatmeal agar (ISP medium no. 3), inorganic saltsstarch agar (ISP medium no. 4), and glycerol-asparagine agar (ISP medium no. 5) (13).

Cultural characteristics. The cultural characteristics on nine kinds of media described by Shirling and Gottlieb (13) and by Waksman (22) were determined. Inoculations of the media were made by the method of Shirling and Gottlieb (13). Cultures were incubated at $27^{\circ} \mathrm{C}$ for 14 days.

Physiological characteristics. The physiological properties of strain $\mathrm{KC}-7038$ were determined as follows. The temperature range for growth and the temperature for optimum growth were determined on yeast extract-malt extract agar (ISP medium no. 2) by means of a temperature-gradient incubator (TN-2M, Toyo Kagaku Sangyo Co., Ltd.). Gelatin liquefaction was determined after 14 days at 20 and $27^{\circ} \mathrm{C}$ on a medium composed of the following: gelatin (Difco), $200 \mathrm{~g}$; glucose, $20 \mathrm{~g}$; peptone (Difco), $5 \mathrm{~g}$; and distilled water, $1,000 \mathrm{ml}$. After having been incubated, the cultures were placed in an ice-box to detect liquefaction. Starch hydrolysis was determined by the starchiodine reaction after incubation of petri dish cultures on inorganic salts-starch agar (ISP medium no. 4) at $27^{\circ} \mathrm{C}$ for 14 days. The determination of milk peptonization and coagulation was made in 14-day-old skimmilk cultures (skim milk [Difco], $100 \mathrm{~g}$ and distilled water, $1,000 \mathrm{ml}$ ) at $27^{\circ} \mathrm{C}$. Melanoid pigment production was studied with tyrosine agar (ISP medium no. 7), peptone-yeast extract-iron agar (ISP medium no. 6), and tryptone-yeast extract broth (ISP medium no. 1) (13).

Carbon utilization. Carbon utilization was examined by the method of Pridham and Gottlieb (11). Pridham and Gottlieb's basal mineral salts agar ( $\mathrm{CuSO}_{4}$ omitted) and Czapek agar (22) were also employed in this study. The results of the tests for ability to grow with each of nine carbon sources were recorded after 14 days of incubation at $27^{\circ} \mathrm{C}$.

Cell wall analysis. The whole-cell analysis of the cell wall of strain KC-7038 was performed by the method of Staneck and Roberts (20).

\section{RESULTS}

Morphological characteristics. The aerial mycelium was moderately short (40 to $60 \mu \mathrm{m}$ in length), simply branched, and formed spore chains. Each spore chain consisted of 20 or more spores and formed a coil with a few turns (Fig. 1). Fragmentation of substrate mycelium, sclerotium formation, sporangium formation, and flagellated spores were not observed. Spores were ellipsoidal to cylindrical, 0.5 to 0.6 by 0.8 to $1.2 \mu \mathrm{m}$ in size, with smooth to slightly rough surfaces (Fig. 2 and 3).

Cultural characteristics. The cultural char- 


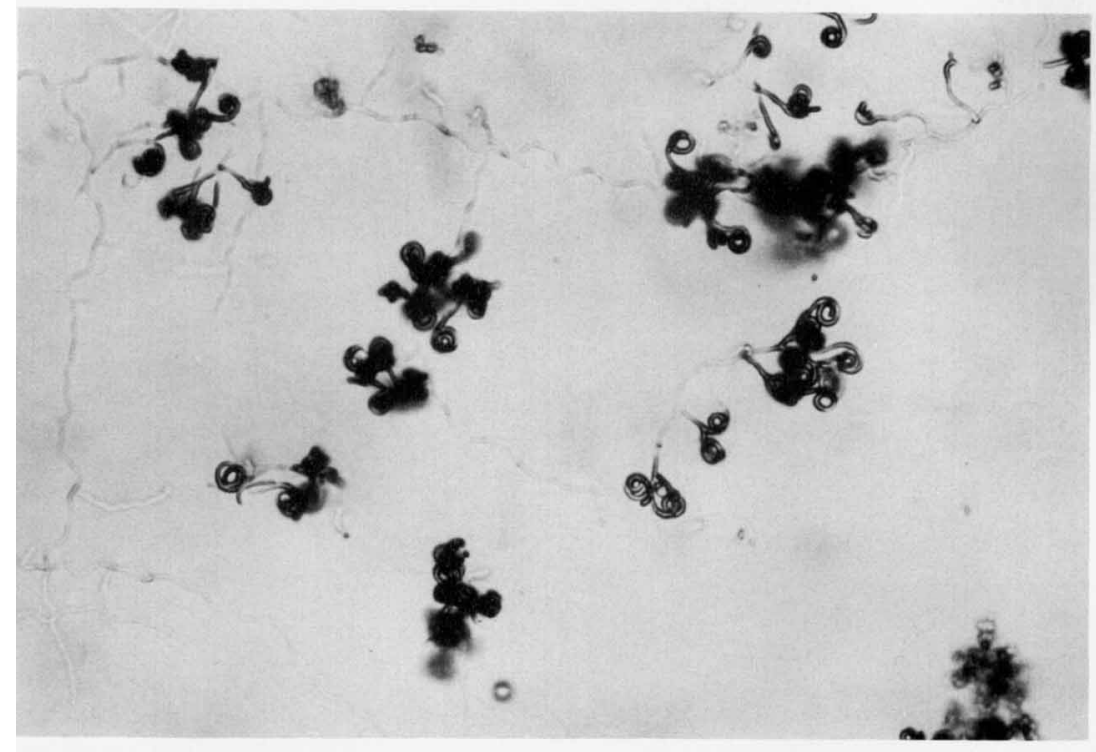

FIG. 1. Sporulating aerial mycelium of strain KC-7038. Coiled spore chains on inorganic salts-starch agar, $27^{\circ} \mathrm{C}$ for 14 days. Optical microscope. Magnification, $\times 870$.

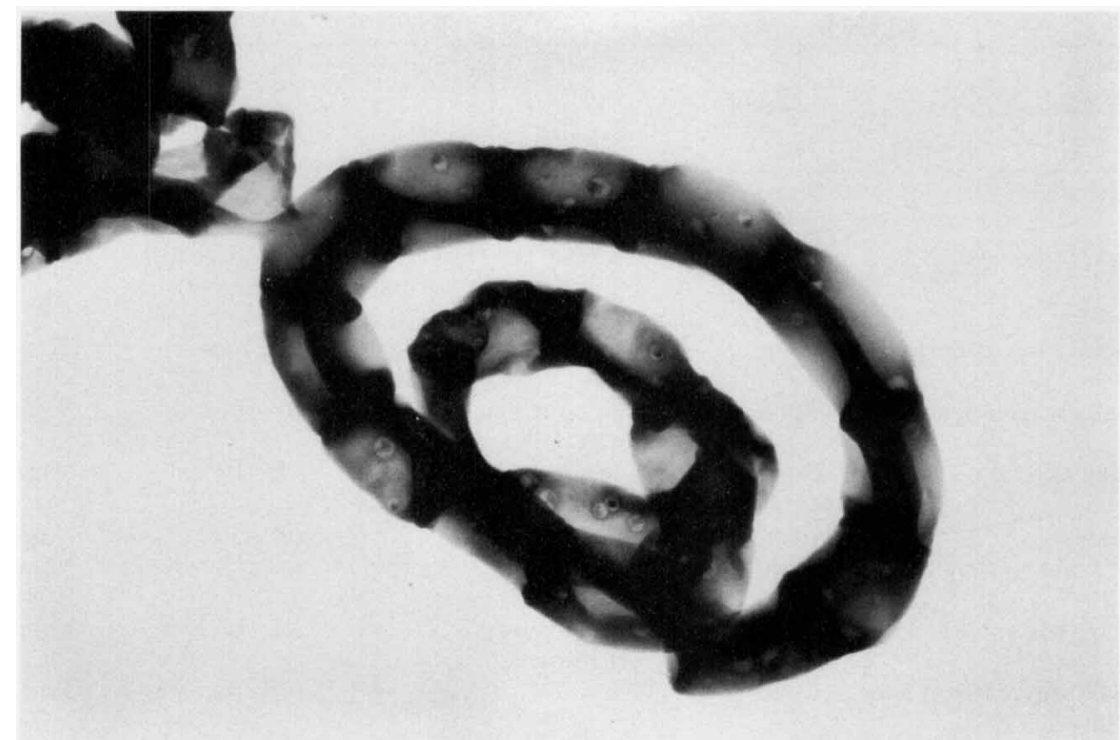

Fig. 2. Smooth spores of strain KC-7038 on inorganic salts-starch agar, $27^{\circ} \mathrm{C}$ for 14 days. Transmission electron microscope. Magnification, $\times 18,000$.

acteristics of strain KC-7038 are shown in Table 1. The colors of the aerial masses produced on sucrose-nitrate agar, glucose-asparagine agar, inorganic salts-starch agar, and oatmeal agar were identified as belonging to the Gray color-series (6). The reverse side of the growth was colorless to buff with all of the media used in this study. A distinct diffusible pigment was not produced except for a faint yellow color in peptone-yeast extract-iron agar.

Physiological characteristics. Growth of strain KC-7038 was noted between 17 and $37^{\circ} \mathrm{C}$. Optimum growth occurred between 27 and $34^{\circ} \mathrm{C}$. Gelatin liquefaction and starch hydrolysis were positive. Milk peptonization and coagulation could not be determined for this strain because 


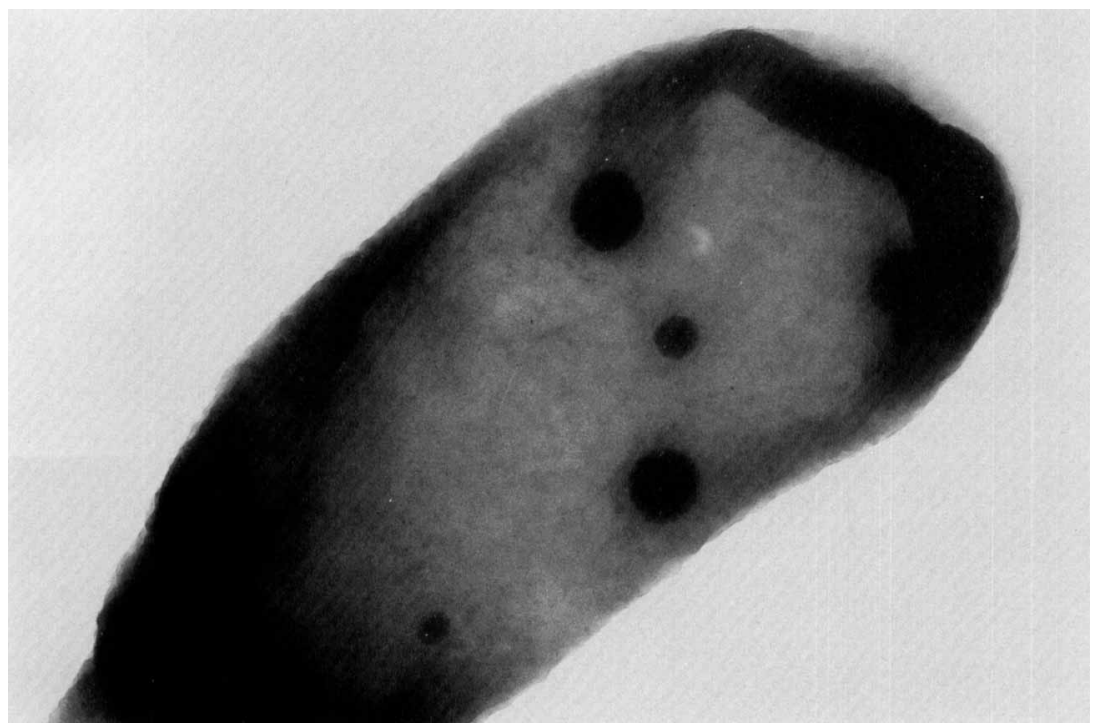

FIG. 3. Slightly rough surface on spore of strain $\mathrm{KC}$ - 7038 on inorganic salts-starch agar, $27^{\circ} \mathrm{C}$ for 14 days. Transmission electron microscope. Magnification, $\times 57,000$.

TABLE 1. Cultural characteristics of strain KC-7038

\begin{tabular}{|c|c|c|c|c|}
\hline \multirow[b]{2}{*}{ Medium } & \multirow[b]{2}{*}{ Growth } & \multicolumn{2}{|c|}{ Cultural characteristics $^{\alpha}$} & \multirow{2}{*}{$\begin{array}{l}\text { Diffusible pig- } \\
\text { ment }\end{array}$} \\
\hline & & Aerial mycelium ${ }^{b}$ & $\begin{array}{l}\text { Reverse side of } \\
\text { colony }\end{array}$ & \\
\hline Sucrose-nitrate agar & Poor & $\begin{array}{l}\text { Moderate, powdery, } 21 \mathrm{i} \\
\text { (covert brown) }\end{array}$ & Colorless & None \\
\hline Glucose-asparagine agar & Moderate & $\begin{array}{l}\text { Moderate, powdery, a } \\
\text { (white) to } 21 \mathrm{i} \text { (covert } \\
\text { brown) }\end{array}$ & $1 \frac{1}{2} \mathrm{ca}$ (Cream) & None \\
\hline $\begin{array}{l}\text { Glycerol-asparagine agar (ISP } \\
\text { no. 5) }\end{array}$ & Poor & Poor, powdery, a (white) & Colorless & None \\
\hline $\begin{array}{l}\text { Inorganic salts-starch agar (ISP } \\
\text { no. 4) }\end{array}$ & Good & $\begin{array}{l}\text { Good, powdery, a (white) } \\
\text { to } 3 \text { fe (silver gray) }\end{array}$ & 3ba (Pearl) & None \\
\hline Tyrosine agar (ISP no. 7) & Good & $\begin{array}{l}\text { Moderate, powery, a } \\
\text { (white) }\end{array}$ & $2 \mathrm{db}$ (Ivory) & None \\
\hline Nutrient agar & Good & None & $2 \mathrm{fb}(\mathrm{Buff})$ & None \\
\hline $\begin{array}{l}\text { Yeast extract-malt extract agar } \\
\text { (ISP no. } 2 \text { ) }\end{array}$ & Good & Poor, powdery, a (white) & 2ea (Lt. wheat) & None \\
\hline Oatmeal agar (ISP no. 3) & Moderate & $\begin{array}{l}\text { Good, powdery, } 21 \mathrm{i} \text { (cov- } \\
\text { ert brown) }\end{array}$ & 2ea (Lt. wheat) & None \\
\hline $\begin{array}{l}\text { Peptone-yeast extract-iron agar } \\
\text { (ISP no. 6) }\end{array}$ & Good & None & $1 \frac{1}{2} \mathrm{ca}$ (Cream) & Trace of yellow \\
\hline
\end{tabular}

The color codes and names used in this study are from the Color Harmony Manual, 4th ed. (6).

${ }^{b}$ The amount of vegetative growth and degree of formation of aerial mycelium are rated on a scale of excellent, good, moderate, poor, and none.

of its lack of ability to grow in the skim milk medium used. Melanoid pigment was not produced in tyrosine agar, peptone-yeast extractiron agar, or tryptone-yeast extract broth.

Carbon utilization. No growth or only a trace of growth occurred with each carbon source tested, namely L-arabinose, D-xylose, Dglucose, D-fructose, sucrose, $i$-inositol, L-rham- nose, raffinose, and D-mannitol, in Pridham and Gottlieb's basal medium. Growth also occurred with glucose or xylose when $\mathrm{CuSO}_{4}$ was removed from the abovementioned basal medium. Therefore, the utilization of carbon sources by strains KC-7038 and "S. pyridomyceticus" ISP 5024 was compared on Pridham and Gottlieb's basal mineral salts agar (ISP medium no. 9) (11), on 
$\mathrm{CuSO}_{4}$-free Pridham and Gottlieb's basal mineral salts agar, and on Czapek agar (see Table 2).

Cell wall analysis. An analysis of whole-cell hydrolysates of strain KC-7038 showed that the cell wall contained LL-diaminopimelic acid. Accordingly, the cell wall of this strain was believed to be of Type I of Becker et al. (1).

\section{DISCUSSION}

Strain KC-7038 was compared with known Streptomyces species described in Bergey's Manual of Determinative Bacteriology, 8th edition (12), and in the ISP reports by Shirling and Gottlieb (14-17). "S. pyridomyceticus" ISP 5024 $(9,15,21)$, S. sulphureus ISP $5104(17,22)$, and "S. thermoflavus" ISP $5574(10,17)$ were sorted out as strains related to strain $\mathrm{KC}-7038$ based on the following: sporophores with coiled spore chains, spores with smooth surfaces, and no or questionable utilization of $\mathrm{D}$-glucose with Pridham and Gottlieb's basal medium.

With respect to the strains cited above, $S$. sulphureus ISP 5104 is distinguished from strain $\mathrm{KC}-7038$ by its yellow aerial mass color and by its ability to grow in skim milk medium. " $S$. thermoflavus" ISP 5574 is also distinguished from strain KC-7038 by its yellow to deep brown or orange color of reverse growth and by its ability to grow at high temperatures (above $37^{\circ} \mathrm{C}$ ). "S. pyridomyceticus" ISP 5024 also differs from strain KC-7038 by its sparse aerial mycelium, its inability to liquefy gelatin, and its ability to grow in skim milk medium. However, it does resemble strain KC-7038 in its inability to grow, or to show only a trace of growth, on
Pridham and Gottlieb's basal mineral salts agar. Consequently, the carbon-utilization pattern of "S. pyridomyceticus" ISP 5024 was compared to that of strain KC-7038 on $\mathrm{CuSO}_{4}$-free Pridham and Gottlieb's basal mineral salts agar and Czapek agar (Table 2). As shown in Table 2, clear differences in sucrose utilization between strains $\mathrm{KC}-7038$ and "S. pyridomyceticus" ISP 5024 were observed both with the $\mathrm{CuSO}_{4}$-free Pridham and Gottlieb's basal mineral salts agar and with Czapek agar medium. Since we did not find any known species of Streptomyces to be identical with strain KC-7038, we regard this strain as belonging to a new species of Streptomyces. For this species we propose the name Streptomyces sannanensis (san.nan.en'sis. M. L. adj. sannanensis of Sannan; named for Sannan Town, Hikami District, Hyogo Prefecture, Japan, the source of the soil from which the organism was isolated).

A description of the new species follows.

Streptomyces sannanensis sp. nov. Spore chain morphology: Section Spirales. Mature spore chains generally moderately short, often with 20 or more spores per chain.

Spore surface: Smooth.

Color of colony: Aerial mass color in the Gray color-series on sucrose-nitrate agar, glucose-asparagine agar, inorganic salts-starch agar, and oatmeal agar.

Reverse side of colony: No distinctive pigments (colorless to buff in color) on all media.

Diffusible pigment: Melanoid pigments are not formed in peptone-yeast extract-iron agar, tyrosine agar, or tryptone-yeast extract broth. No pigment other than a trace of yellow is produced in the media used.

TABLE 2. Comparison of carbon utilization patterns of strains KC-7038 and "S. pyridomyceticus" ISP 5024

\begin{tabular}{|c|c|c|c|c|c|c|}
\hline \multirow[b]{3}{*}{ Carbon source } & \multicolumn{6}{|c|}{ Carbon source utilization by: ${ }^{a}$} \\
\hline & \multicolumn{3}{|c|}{ Strain KC-7038 } & \multicolumn{3}{|c|}{ "S. pyridomyceticus" ISP 5024} \\
\hline & $\begin{array}{l}\text { Pridham } \\
\text { and } \\
\text { Gottlieb's } \\
\text { basal min- } \\
\text { eral salts } \\
\text { agar (ISP } \\
\text { no. 9) }\end{array}$ & $\begin{array}{l}\mathrm{CuSO}_{4} \text {-free } \\
\text { Pridham } \\
\text { and } \\
\text { Gottlieb's } \\
\text { basal min- } \\
\text { eral saits } \\
\text { agar }\end{array}$ & $\begin{array}{c}\text { Czapek } \\
\text { agar }\end{array}$ & $\begin{array}{l}\text { Pridham } \\
\text { and } \\
\text { Gottlieb's } \\
\text { basal min- } \\
\text { eral salts } \\
\text { agar (ISP } \\
\text { no. 9) }\end{array}$ & $\begin{array}{c}\mathrm{CuSO}_{4} \text {-free } \\
\text { Pridham } \\
\text { and } \\
\text { Gottlieb's } \\
\text { basal min- } \\
\text { eral salts } \\
\text { agar }\end{array}$ & $\begin{array}{c}\text { Czapek } \\
\text { agar }\end{array}$ \\
\hline L-Arabinose & - & - & - & - & - & \pm \\
\hline$D-X y l o s e$ & - & + & + & - & - & $\bar{t}$ \\
\hline D-Glucose & - & \pm & \pm & - & \pm & + \\
\hline D-Fructose & - & - & - & - & - & \pm \\
\hline Sucrose & - & - & - & - & + & + \\
\hline$i$-Inositol & - & - & - & - & - & - \\
\hline L-Rhamnose & - & - & - & - & - & - \\
\hline Raffinose & - & - & - & - & - & - \\
\hline D-Mannitol & - & - & - & - & - & - \\
\hline
\end{tabular}

\footnotetext{
${ }^{a}$ All cultures were incubated at $27^{\circ} \mathrm{C}$ for 14 days. Symbols: - , negative response; \pm , doubtful response; + , positive response.
} 
Physiological characteristics: Mesophilic (growth range is from 17 to $37^{\circ} \mathrm{C}$; temperature for optimum growth is between 27 and $34^{\circ} \mathrm{C}$ ). Starch is hydrolyzed and gelatin is liquefied. Does not grow in skim milk medium. Melanoid pigment is not produced.

Carbon utilization: No growth or only a trace of growth with L-arabinose, D-xylose, D-glucose, $D$-fructose, sucrose, $i$-inositol, L-rhamnose, raffinose, or D-mannitol with Pridham and Gottlieb's basal mineral salts agar. On $\mathrm{CuSO}_{4}$-free Pridham and Gottlieb's basal mineral salts agar and Czapek solution agar, D-xylose and D-glucose are utilized for growth; D-glucose gives only faint growth.

Cell wall composition: LL-diaminopimelic acid occurs in whole-cell hydrolysates. The cell wall composition is believed to be of Type I.

Antagonistic properties: Produces sannamycins.

Habitat: Soil.

Type strain: Strain KC-7038. A culture of this strain has been deposited in the American Type Culture Collection, Rockville, Md., where it has been assigned the number 31530 . Because the description given above for the species is based on a single strain, the type strain, the species description also serves as the description of the type strain.

\section{ACKNOWLEDGMENTS}

We thank Y. Okami and M. Hamada of the Institute of Microbial Chemistry for their helpful advice. We also thank A. Seino of Kaken Chemical Co. Ltd. for providing the ISP strain of "Streptomyces pyridomyceticus."

\section{REPRINT REQUESTS}

Address reprint requests to: Dr. Toshihito Mori, Tokyo Research Laboratories, Kowa, Co., Ltd., 2-17-43, Noguchi-cho, Higashimurayama-shi, Tokyo 189, Japan.

\section{LITERATURE CITED}

1. Becker, B., M. P. Lechevalier, and H. Lechevalier. 1965. Chemical composition of cell-wall preparations from strains of various form-genera of aerobic actinomycetes. Appl. Microbiol. 13:236-248.

2. Deushi, T., A. Iwasaki, K. Kamiya, T. Mizoguchi, M. Nakayama, H. Itoh, and T. Mori. 1979. New aminoglycoside antibiotics, sannamycin. J. Antibiot. 32:10611065.

3. Deushi, T., M. Nakayama, I. Watanabe, T. Mori, H. Naganawa, and H. Umezawa. 1979. A new broadspectrum aminoglycoside antibiotic complex, sporaricin. III. The structure of sporaricins A and B. J. Antibiot. 32:187-192.

4. Egan, S. E., R. S. Stanaszek, M. Cirovic, S. L. Mueller, J. Tadanier, J. R. Martin, P. Collum, A. W. Goldstein, R. L. DeVault, A. C. Sinclair, E. E. Fager, and L. A. Mitscher. 1977. Fortimicins A and B, new aminoglycoside antibiotics. III. Structural identification. J. Antibiot. 30:552-563.
5. Iwasaki, A., H. Itoh, and T. Mori. 1979. A new broadspectrum aminoglycoside antibiotic complex, sporaricin. II. Taxonomic studies on the sporaricin producing strain Saccharopolyspora hirsuta subsp. kobensis nov. subsp. J. Antibiot. 32:180-186.

6. Jacobson, E., W. C. Grauville, and C. E. Fogs, 1958 Color harmony manual, 4 th ed. Container Corporation of America, Chicago.

7. Nara, T., M. Yamamoto, I. Kawamoto, K. Takayama, R. Okachi, S. Takasawa, T. Sato, and S. Sato. 1977. Fortimicins A and B, new aminoglycoside antibiotics. I. Producing organism, fermentation and biological properties of fortimicins. J. Antibiot. 30:533-540.

8. Okami, Y., K. Hotta, M. Yoshida, D. Ikeda, S. Kondo, and $H$. Umezawa. 1979. New aminoglycoside antibiotics, istamycins A and B. J. Antibiot. 32:964-966.

9. Okami, Y., K. Maeda, and H. Umezawa. 1954. Studies on antibiotic actinomycetes. VIII. On Streptomyces albidofuscus Okami et Umezawa, nov. sp. producing a new antibiotic pyridomycin, J. Antibiot. Tokyo Ser. A 7:55-56.

10. Pridham, T. G. 1970 . New names and new combinations in the order Actinomycetales Buchanan 1917. U.S. Department of Agriculture technical bulletin no. 1424. U.S. Department of Agriculture, Washington, D.C.

11. Pridham, T. G., and G. Gottlieb. 1948. The utilization of carbon compounds by some Actinomycetales as an aid for species determination. J. Bacteriol. 56:107-114.

12. Pridham, T. G., and H. D. Tresner. 1974. Genus I. Streptomyces Waksman and Henrici, p. 748-829. In $\mathrm{R}$. E. Buchanan and N. E. Gibbons (ed.), Bergey's manual of determinative bacteriology, 8 th ed. The Williams \& Wilkins Co., Baltimore.

13. Shirling, E. B., and D. Gottlieb. 1966. Method for classification of Streptomyces species. Int. J. Syst. Bacteriol. 16:313-340.

14. Shirling, E. B., and D. Gottlieb. 1968. Cooperative description of type cultures of Streptomyces. II. Species descriptions from first study. Int. J. Syst. Bacteriol. 18: 69-189.

15. Shirling, E. B., and D. Gottlieb. 1968. Cooperative description of type cultures of Streptomyces. III. Additional species descriptions from first and second studies. Int. J. Syst. Bacteriol. 18:279-392.

16. Shirling, E. B., and D. Gottlieb. 1969. Cooperative description of type cultures of Streptomyces. IV. Species description from second, third and fourth studies. Int. J. Syst. Bacteriol. 19:391-512.

17. Shirling, E. B., and D. Gottlieb. 1972. Cooperative description of type strains of Streptomyces. V. Additional description. Int. J. Syst. Bacteriol. 22:256-394.

18. Shomura, T., M. Kojima, J. Yoshida, M. Itō, S. Amano, K. Totsugawa, T. Niwa, S. Inouye, T. Itō, and T. Niida. 1980. Studies on a new aminoglycoside antibiotic, dactimicin. I. Producing organism and fermentation. J. Antibiot. 33:924-930.

19. Skerman, V. B. D., V. McGowan, and P. H. A. Sneath. 1980. Approved lists of bacterial names. Int. J. Syst. Bacteriol. 30:225-420.

20. Staneck, J. L., and G. D. Roberts. 1974. Simplified approach to identification of aerobic actinomycetes by thin-layer chromatography. Appl. Microbiol. 28:226231.

21. Umezawa, H., and Y. Okami. 1957. Changing the name of pyridomycin producing streptomycetes. J. Antibiot. Tokyo Ser. A 10:172.

22. Waksman, S. A. 1961. The actinomycetes, vol. 2. Classification, identification and description of genera and species. The Williams \& Wilkins Co., Baltimore. 